\title{
Comparison of different primes for PCR-based diagnosis of cutaneous leishmaniasis
}

Authors

Diego Molina de Oliveira ${ }^{1}$ Maria Valdrinez

Campana Lonardoni ${ }^{2}$ Ueslei Teodoro ${ }^{2}$

Thais Gomes Verzignassi Silveira

'MD; Postgraduate Student, Universidade Estadual de Maringá, PR, Brazil ${ }^{2} \mathrm{MD}$, PhD; Professor Departament of Clinical Analysis, Universidade Estadual de Maringá, PR, Brazil
Submitted on: 09/29/2010 Approved on: 02/24/2011

\section{Correspondence to: Thais GV Silveira Departamento de Análises Clínicas e Biomedicina \\ Universidade Estadual de Maringá \\ Av. Colombo 5790 Maringá, Paraná, Brazil 87020-900 \\ tgvsilveira@uem.br}

\section{Financial Support:} Fundação Araucária and Conselho Nacional de Desenvolvimento Científico e Tecnológico (CNPq) (Process No. 410550/2006-0)

We declare no conflict of interest.

\begin{abstract}
Objective: The objective of this study was to analyze different primers that are commonly used in epidemiological studies for the detection of Leishmania DNA by PCR, and to compare them to the conventional direct parasite search for American cutaneous leishmaniasis (ACL) diagnosis. Material and methods: Five pairs of primers, four of them derived from Leishmania kDNA sequences (MP3H-MP1L; B1-B2; LBF1-LBR1; 13A-13B), and one derived from the SL RNA (mini-exon) gene repeat (LU5A-LB3C), reported previously, were used. Results: The MP3H-MP1L primers were the best at amplifying the DNA, detecting 2 fg of Leishmania spp. DNA. The 13A-13B primers presented the worst performance, detecting $512 \times 10^{3} \mathrm{fg}$ of DNA. Conclusion: The wide variation in the analytical sensitivity of the primers used in the PCR, and the significant differences from the conventional method of ACL diagnosis found in this study, emphasize the importance of standardizing the PCR technique, analyzing sensitivity, and selecting suitable oligonucleotide primers.
\end{abstract}

Keywords: leishmaniasis; polymerase chain reaction; Leishmania; DNA primers.

[Braz J Infect Dis 2011;15(3):204-210]@Elsevier Editora Ltda.

\section{INTRODUCTION}

Leishmaniases are infectious-parasitic diseases caused by protozoa of the genus Leishmania. They are transmitted by the bite of female dipterans of the family Psychodidae, subfamily Phlebotominae, generally known as sandflies. They have a wide spectrum of clinical forms, involving the skin, mucosa, and internal organs. ${ }^{1-3}$

The leishmaniases are found across four continents, and are endemic in 88 countries, 72 of which are developing countries. It is estimated that there is a global human prevalence of 12 million cases, with 600,000 new cases a year for visceral forms and 1-1.5 million new cases for cutaneous forms. ${ }^{4}$ In Brazil, American Cutaneous Leishmaniasis (ACL) is caused by at least six different species of Leishmania, with the majority of cases involving Leishmania (Viannia) braziliensis, ${ }^{5}$ especially in the southern region of the country. ${ }^{6}$

The classic techniques of ACL diagnosis have many limitations. Microscopic examinations of skin scrapings, although quick and of low cost, have limitations with regard to sensitivity, especially for chronic lesions. In vitro culture techniques are susceptible to micro- biological contamination, and are difficult to grow due to the particular requirements of the different parasites. ${ }^{7}$ The Montenegro skin test has good specificity, as it activates the delayed hypersensitivity mechanism, but cannot distinguish between present and past infections. Serological diagnostic techniques using crude antigens have the disadvantage of cross-reactivity of Leishmania antigens with antibodies induced by other kinetoplastids, such as Trypanosoma cruzi. ${ }^{8,9}$ Furthermore, serological techniques have low sensitivity, because of the low antibody titers characteristic of ACL. ${ }^{1}$ Molecular techniques, such as the polymerase chain reaction (PCR), offer an alternative approach to finding the parasites in clinical samples. ${ }^{10}$ Because of the molecular specificity of PCR, detection and genetic characterization of Leishmania can be carried out simultaneously. ${ }^{11,12}$

The extensive literature on the molecular diagnosis of ACL has provided various alternatives, from the use of primers that amplify sequences of specific Leishmania species to primers that amplify sequences common to all the species. ${ }^{13,14}$ The objective of this study was to analyze different PCR primers that are commonly used in epidemiological studies for 
the detection of Leishmania, and to compare them in the diagnosis of ACL in biological samples taken from dogs and humans in an endemic region.

\section{MATERIALS AND METHODS}

\section{Biological samples}

Seventy-three DNA samples, all originating from an ACL-endemic region, were used in the study. The samples were stored at $-18^{\circ} \mathrm{C}$ in the Laboratory of Leishmaniases of Universidade Estadual de Maringá. These samples were grouped according to the direct parasite search results. Twenty-six of the samples came from dogs (from blood, lesion scrapings, and lesion biopsies) originating from the municipalities of Mariluz, Abatiá, Rio Bonito do Iguaçu, Santa Cecília do Pavão, and Nova América da Colina (all in the State of Paraná, Brazil). Forty-seven samples (lesion scrapings) came from humans from the northeast region of Paraná, who were treated at the Laboratório de Ensino e Pesquisa em Análises Clínicas (LEPAC) of the Universidade Estadual de Maringá, for ACL diagnosis.

Blood samples were collected and added to an equal volume of ACD solution ( $25 \mathrm{mM}$ citric acid; $50 \mathrm{mM}$ sodium citrate; $81 \mathrm{mM}$ glucose). The material was frozen at $-18^{\circ} \mathrm{C}$ until DNA extraction. The DNA was extracted from the blood by either the chloroform-phenol method $^{15}$ or the guanidine-phenol method. ${ }^{16}$ The DNA sediment was then resuspended in $50 \mu \mathrm{L}$ of TE buffer (10 mM TRIS; 1 mM EDTA; pH 8.0).

The lesion scraping and biopsy samples were added to $100 \mu \mathrm{L}$ of STE buffer (10 mM TRIS; 1 mM EDTA; $0.1 \mathrm{M}$ $\mathrm{NaCl} ; \mathrm{pH}$ 8.0). DNA from lesion biopsies was extracted using the Puregene $e^{\varpi}$ kit (Gentra, USA). For the extraction of DNA from lesion-scraping samples, the tubes containing the material were incubated at $95^{\circ} \mathrm{C}$ for $30 \mathrm{~min}$ in a Thermocycler (Biometra PC, Germany), centrifuged at $13,000 \mathrm{x} g$ for $1 \mathrm{~min}$, and the supernatant was then transferred to another tube and stored at $-18^{\circ} \mathrm{C}$ until use.

The DNA was quantified by the Quant-iT ${ }^{\mathrm{TM}} \mathrm{dsDNA} H S$ Assay Kit and the Qubit ${ }^{\mathrm{TM}}$ fluorometer (Invitrogen, USA).

\section{Direct parasite search (DP)}

For the direct parasite search from canine and human samples, slides of lesion material were stained with Giemsa and inspected for the presence of amastigote forms.

\section{Parasites}

Promastigote forms of L. (V.) braziliensis (MHOM/BR/1987/ M11272) were cultured in Medium 199 (Invitrogen ${ }^{\circ}$, USA) containing $10 \%$ bovine fetal serum (Invitrogen ${ }^{\circ}$, USA), $20 \mathrm{mM} \mathrm{L}$-glutamine (Invitrogen $^{\circ}$, USA), and 1\% human urine, at $25^{\circ} \mathrm{C}$ in a B.O.D. incubator (Logen Scientific, Brazil) until they reached the stationary growth phase.

\section{Extraction of Leishmania DNA}

The parasites (approximately $50 \mathrm{~mL}$ of culture) were washed three times by centrifugation $(1,600 \mathrm{x} \mathrm{g}$ for $10 \mathrm{~min})$ in cold phosphate-buffered saline (PBS). The DNA was extracted by the guanidine-phenol method, ${ }^{16}$ resuspended in TE buffer, quantified using the Quant-iT ${ }^{\text {TM }}$ dsDNA BR Assay Kit and the Qubit $^{\mathrm{TM}}$ fluorometer (Invitrogen, USA), and serially diluted $(1,024 \mathrm{ng} / \mu \mathrm{L}$ to $0.5 \mathrm{fg} / \mu \mathrm{L})$ for the PCR primer sensitivity tests.

\section{Polymerase chain reaction (PCR)}

Five different kinetoplast and miniexon sequence pairs of primers were used: MP3H (5'-GAA CGG GGT TTC TGT ATG C-3') and MP1L (5'-TAC TCC CCG ACA TGC CTC TG-3'), ${ }^{17}$ B1 (5'-GGG GTT GGT GTA ATA TAG TGG-3') and B2 (5'-CTA ATT GTG CAC GGG GAG G-3'), ${ }^{18}$ LU5A (5'-TTT ATT GGT ATG CGA AAC TTC-3') and LB3C (5'-CGT(C/G)CCGAACCCCGTGTC- 3 '), ${ }^{19}$ LBF1 (5'-AAA TTC GCG TTT TTT GGC CTC CCC G-3') and LBR1 (5'GCA TAA ACT AGA GAC GGA ACA GAG-3'), ${ }^{20}$ and 13A (5'-GTG GGG GAG GGG CGT TCT-3') and 13B (5'-ATT TTA CAC CAA CCC CCA GTT-3'). ${ }^{21}$ The reaction medium $(25 \mu \mathrm{L})$ contained $1 \mu \mathrm{M}$ of each of the primers (Invitrogen ${ }^{\circledR}$, Brazil), 0.2 mM dNTP (Invitrogen ${ }^{\circledR}$, USA), $1 \mathrm{U}$ Taq DNA polymerase (Invitrogen ${ }^{\circ}$, USA), $1.5 \mathrm{mM}$ $\mathrm{MgCl}_{2}, 1 \mathrm{X}$ enzyme buffer, and $2 \mu \mathrm{L}$ of the extracted DNA. The amplification was carried out in a PC Thermocycler (Biometra, Germany), using an initial heating of $95^{\circ} \mathrm{C}$ for $5 \mathrm{~min}$. Each cycle was divided into three stages: denaturation $\left(95^{\circ} \mathrm{C}-1.5 \mathrm{~min}\right)$, annealing, and elongation $\left(72^{\circ} \mathrm{C}-\right.$ $2 \mathrm{~min})$. The PCR conditions were optimized for each of the five primer sets to detect $L$. (V.) braziliensis DNA template. Table 1 summarizes the specifications for each protocol used in the PCR. After the reaction, the material was kept at $72^{\circ} \mathrm{C}$ for $10 \mathrm{~min}$, and the amplified product was then stored at $4^{\circ} \mathrm{C}$ until use. The products of the amplification were submitted to electrophoresis at $10-15 \mathrm{~V} / \mathrm{cm}$ in agarose gel, and stained with $0.1 \mu \mathrm{g} / \mathrm{mL}$ ethyl bromide. For every five samples amplified, one positive control $[L .(V)$. braziliensis DNA] and one negative control (ultrapure water) were added. The presence of bands was then observed in a transilluminator (Macro Vue UV-20, Hoefer).

\section{Statistical analysis}

Proportions and confidence intervals were calculated by Mid-P exact test using OpenEpi version 2.2.1 software, at a significance level of $5 \%$.

\section{Ethical aspects}

All procedures were performed according to protocols approved by the Committee on Research Animal Care of Universidade Estadual de Maringá (report 027/2005 and 070/2005) and the Permanent Ethics Committee in Research involving Human Beings (report 451/2007). 
Table 1. Polymerase chain reaction conditions and results with different pairs of oligonucleotide primers on biological samples from dogs and humans with suspected American cutaneous leishmaniasis lesions, according to diagnosis by direct parasite search

\begin{tabular}{|c|c|c|c|c|c|}
\hline Characteristic & MP3H-MP1L & B1-B2 & LU5A-LB3C & LBF1-LBR1 & 13A-13B \\
\hline PCR product & $\begin{array}{c}\text { kDNA } \\
\text { minicircle } \\
\text { fragment } \\
\text { of } L . \text { (Viannia) } \\
(70 \mathrm{pb})\end{array}$ & $\begin{array}{l}\text { kDNA } \\
\text { minicircle } \\
\text { of } L . \\
\text { braziliensis } \\
\text { complex } \\
\text { (750 pb) }\end{array}$ & $\begin{array}{l}\text { SL RNA } \\
\text { gene repeat } \\
\text { region of } L \text {. } \\
\text { braziliensis } \\
\text { complex } \\
\text { (146-149 pb) }\end{array}$ & $\begin{array}{c}\text { kDNA } \\
\text { minicircle } \\
\text { fragment of } \\
\text { L. (V.) } \\
\text { braziliensis } \\
\text { (536 pb) }\end{array}$ & $\begin{array}{c}\text { kDNA } \\
\text { minicircle } \\
\text { fragment } \\
\text { of Leishmania } \\
(120 \mathrm{pb})\end{array}$ \\
\hline \multicolumn{6}{|l|}{ Cycles } \\
\hline Annealing & $57^{\circ} \mathrm{C}-1.5 \mathrm{~min}$ & $60.5^{\circ} \mathrm{C}-1.5 \mathrm{~min}$ & $55^{\circ} \mathrm{C}-1.5 \min$ & $58^{\circ} \mathrm{C}-1.5 \mathrm{~min}$ & $57^{\circ} \mathrm{C}-1.5 \mathrm{~min}$ \\
\hline $\begin{array}{l}\text { No. of cycles } \\
\text { Sensitivity of }\end{array}$ & 30 & 35 & 30 & 26 & 30 \\
\hline $\begin{array}{l}\text { PCR with } \\
\text { L. braziliensis } \\
\text { DNA (fg) }\end{array}$ & 2 & 4 & 256 & $64 \times 10^{3}$ & $512 \times 10^{3}$ \\
\hline \multicolumn{6}{|l|}{$\begin{array}{l}\text { Groups } \\
\text { (biological } \\
\text { sample) - (P/T) }\end{array}$} \\
\hline $\begin{array}{l}\text { Dogs } \mathrm{DP}^{+} \\
\text {(lesion } \\
\text { scraping } \\
\text { and biopsy) }\end{array}$ & $\begin{array}{c}8 / 8 \\
100 \% \\
(95 \% \mathrm{CI} \\
68.77-100.00)\end{array}$ & $\begin{array}{c}4 / 8 \\
50.0 \% \\
(95 \% \mathrm{CI} ; \\
18.41-81.59)\end{array}$ & $\begin{array}{c}2 / 8 \\
25.0 \% \\
(95 \% \mathrm{CI} ; \\
4.43-61.17)\end{array}$ & $\begin{array}{c}0 / 8 \\
0 \% \\
(95 \% \mathrm{CI} \\
0.0-31.23)\end{array}$ & $\begin{array}{c}0 / 8 \\
0 \% \\
(95 \% \mathrm{CI} \\
0.0-31.23)\end{array}$ \\
\hline $\begin{array}{l}\text { Dogs } \mathrm{DP}^{-} \\
\text {(blood) }\end{array}$ & $\begin{array}{c}15 / 18 \\
83.3 \% \\
(95 \% \mathrm{CI} ; \\
61.03-95.58)\end{array}$ & $\begin{array}{c}14 / 18 \\
77.8 \% \\
(95 \% \mathrm{CI} ; \\
54.69-92.51)\end{array}$ & $\begin{array}{c}6 / 18 \\
33.3 \% \\
(95 \% \mathrm{CI} ; \\
14.77-56.90)\end{array}$ & $\begin{array}{c}5 / 18 \\
27.7 \% \\
(95 \% \mathrm{CI} \\
10.96-51.27)\end{array}$ & $\begin{array}{c}6 / 18 \\
33.3 \% \\
(95 \% \mathrm{CI} ; \\
14.77-56.90)\end{array}$ \\
\hline $\begin{array}{l}\text { Humans } \mathrm{DP}^{+} \\
\text {(lesion } \\
\text { scraping) }\end{array}$ & $\begin{array}{c}27 / 27 \\
100 \% \\
(95 \% \mathrm{CI} \\
89.50-100.00)\end{array}$ & $\begin{array}{c}27 / 27 \\
100 \% \\
(95 \% \mathrm{CI} \\
89.50-100.00)\end{array}$ & $\begin{array}{c}26 / 27 \\
96.3 \% \\
(95 \% \mathrm{CI} ; \\
83.06-99.82)\end{array}$ & $\begin{array}{c}15 / 27 \\
55.6 \% \\
(95 \% \mathrm{CI} ; \\
36.73-73.25)\end{array}$ & $\begin{array}{c}6 / 27 \\
22.2 \% \\
(95 \% \mathrm{CI} \\
9.53-40.61)\end{array}$ \\
\hline $\begin{array}{l}\text { Humans DP- } \\
\text { (lesion } \\
\text { scraping) }\end{array}$ & $\begin{array}{c}12 / 20 \\
60 \% \\
(95 \% \mathrm{CI} ; \\
37.89-79.39)\end{array}$ & $\begin{array}{c}7 / 20 \\
35.0 \% \\
(95 \% \mathrm{CI} \\
16.77-57.30 \%)\end{array}$ & $\begin{array}{c}0 / 20 \\
0 \% \\
(95 \% \mathrm{CI} \\
00.00-13.91)\end{array}$ & $\begin{array}{c}0 / 20 \\
0 \% \\
(95 \% \mathrm{CI} \\
00.00-13.91)\end{array}$ & $\begin{array}{c}0 / 20 \\
0 \% \\
(95 \% \mathrm{CI} \\
00.00-13.91)\end{array}$ \\
\hline
\end{tabular}

P, positive samples; T, total samples; DP, direct parasite search.

${ }^{+}$, positive results; ' , negative results. 


\section{RESULTS}

Sensitivity analysis of the five pairs of primers showed different detection limits for Leishmania DNA. The MP3H-MP1L pair of primers performed best, detecting $2 \mathrm{fg}$ of Leishmania (Viannia) DNA. Conversely, the 13A-13B primers presented the worst performance, detecting only $512 \times 10^{3} \mathrm{fg}$ of Leishmania spp. DNA (Figure 1 and Table 1).

The analyses of eight samples of lesion scrapings and biopsies from dogs with ACL lesions that showed positive DP results had a positivity rate of $100 \%$ for PCR using the $\mathrm{MP} 3 \mathrm{H}-\mathrm{MP} 1 \mathrm{~L}$ primers, compared to a positivity rate of $0.0 \%$ when using the LBF1-LBR1 or 13A-13B primers. Figure 2 shows amplification in clinical samples using MP3H-MP1L primers.

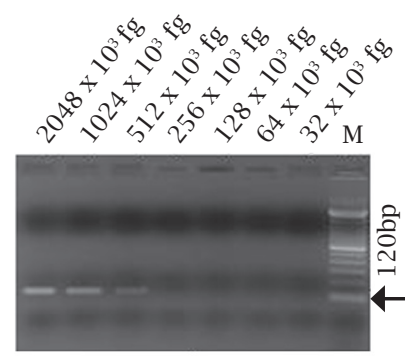

A

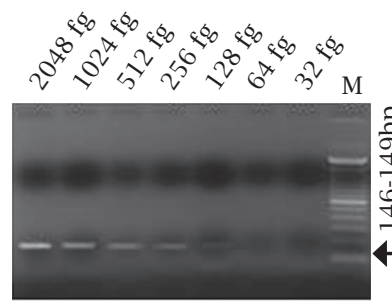

C

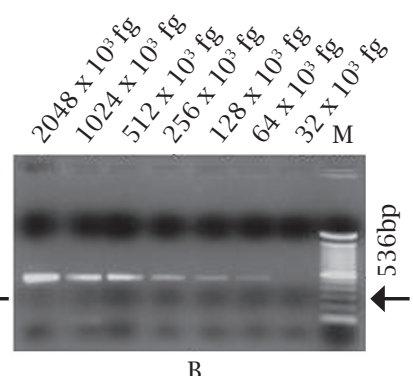

B

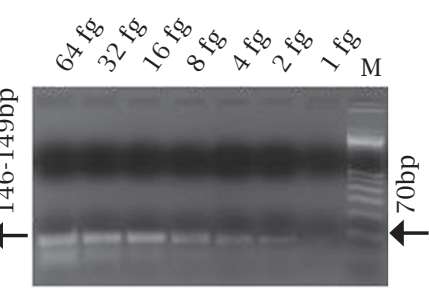

$\mathrm{D}$
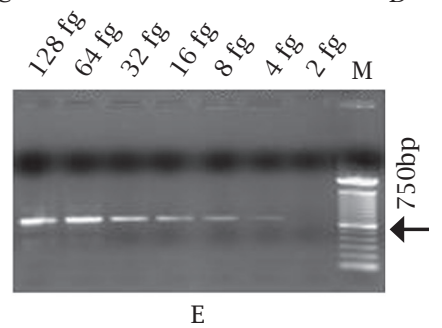

Figure 1: Representative gel showing analytical sensitivity of PCR using as the template a twofold serial dilution of DNA from promastigote forms of L. (V.) braziliensis (MHOM/ BR/1987/M11272). Panel A: 120 bp fragment of the kDNA minicircle region of the genus Leishmania, using 13A-13B primers. Panel B: 536 bp fragment of the kDNA minicircle region of $L$. $(V$.$) braziliensis, using LBR1-LBF1 primers.$ Panel C: 146-149 bp fragment of the SL RNA gene repeat region of the $L$. braziliensis complex, using LU5A-LB3C primers. Panel D: 70 bp fragment of the k-DNA minicircle region of the subgenus Leishmania (Viannia), amplified by polymerase chain reaction (PCR) using MP3H-MP1L primers. Panel E: $750 \mathrm{bp}$ fragment of the kDNA minicircle region of species of the L. braziliensis complex, using B1-B2 primers. M, 100 bp molecular marker.

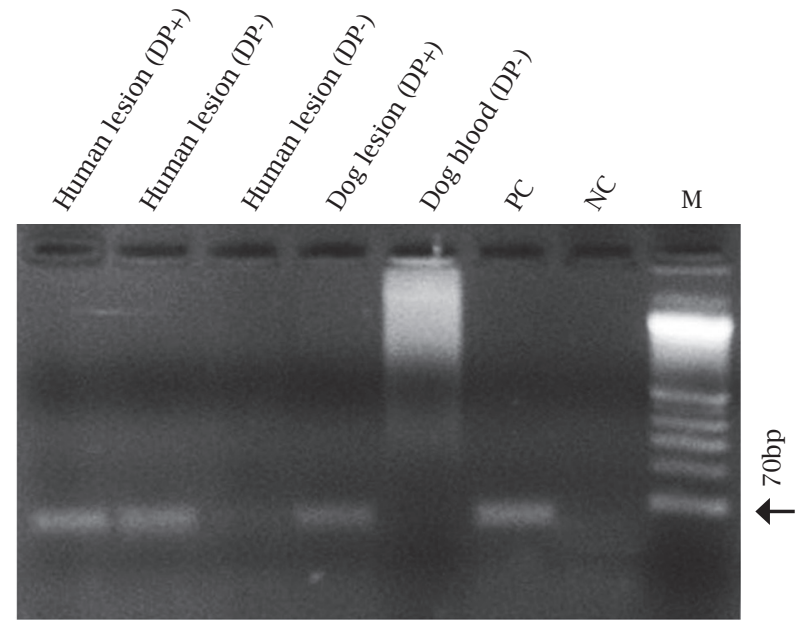

Figure 2: Representative gel showing amplification using MP3H-MP1L primers in clinical samples. Scraping of human and canine cutaneous lesions with positive direct parasite search (DP+), scraping of human cutaneous lesions with negative direct parasite search (DP-) and blood of dog with negative direct parasite search (DP-) of lesion. PC, positive control [(DNA from L. (V.) braziliensis (MHOM/BR/1987/ M11272)]; NC, negative control (reaction mixture); M, 100 bp molecular marker.

In 18 samples of DNA extracted from the blood of dogs with suspected ACL lesions, even though DP produced negative results, the positivity rate for PCR when using the MP3H-MP1L primers was $83.3 \%$, and $27.7 \%$ when using the least-sensitive primers (LBF1-LBR1).

In the 27 DNA samples from the ACL lesions of humans that turned out positive DP results, the positivity rate for PCR when using the MP3H-MP1L and B1-B2 primers was again $100 \%$. When using the LU5A-LB3C primers, the positivity rate was $96.3 \%$.

In the 20 DNA samples from lesions of humans with suspected ACL, that had negative DP results, the positivity rate for PCR when using the MP3H-MP1L primers was $60.0 \%$, and with the $\mathrm{B} 1-\mathrm{B} 2$ primers was $35.0 \%$. The PCR turned out negative with LU5A-LB3C primers.

The PCR results for canine and human lesion samples using the MP3H-MP1L primers proved be the most sensitive, demonstrating superior positivity to those of DP for ACL diagnosis: $100 \%$ in the canine and human samples with PD positive and 12/20 (60.0\%) in the samples from humans with lesion suspected of the ACL (Table 1).

High rates of positivity were found for PCR, using the different primers to amplify DNA from blood samples of dogs with suspected ACL lesions from an endemic region, especially with the MP3H-MP1L primers, which had a positivity rate of $83.3 \%$. The analysis of the lesions of these dogs by DP gave negative results. 


\section{DISCUSSION}

We selected five pairs of primers, four of them derived from kDNA sequences and one from SL RNA (mini-exon). The kDNA minicircles are present in a very high copy number $(10,000$ per cell), and the SL RNA gene is present in the nuclear genome as a tandem repeat sequence of approximately 200 copies. ${ }^{19}$ These selected pairs of primers are intended to detect $L$. braziliensis, the main species causing ACL in southern Brazil.

PCR using the MP3H-MP1L primers, which only amplify fragments of the kDNA of species of the subgenus Leishmania (Viannia), proved be very sensitive, being capable of detecting 2 fg of DNA, which is similar to the results reported by Lopes ${ }^{17}$ and Velasquez, ${ }^{15}$ who detected $0.14 \mathrm{fg}$ and $0.9 \mathrm{fg}$ of DNA, respectively. The other pair of primers that showed good sensitivity was B1-B2, which amplifies fragments of the kDNA of species of the L. braziliensis complex, detecting 4 fg of DNA, a value very close to that found by De Bruijn and Baker. ${ }^{18}$

The 13A-13B primers that amplify fragments of the $\mathrm{kDNA}$ of species of Leishmania showed low efficiency, detecting only concentrations higher than 512 pg of DNA. Manna, ${ }^{22}$ using these same primers, but with DNA from Leishmania infantum, demonstrated a sensitivity of $1 \mathrm{pg}$ of DNA. A more significant value of $10 \mathrm{fg}$ of $L$. (V.) braziliensis DNA was found by Rodger. ${ }^{21}$ However, these latter authors used the DNA hybridization method, which results in higher sensitivity and therefore efficiency of the primer. Recently, Marcussi ${ }^{20}$ developed a pair of primers (LBF1-LBR1) capable of amplifying a specific sequence of the kDNA minicircle of $L$. (V.) braziliensis. Data obtained in the present study using this pair showed that it was capable of detecting $64 \mathrm{pg}$ of DNA, showing greater sensitivity in DNA detection compared to the limit of $4 \mathrm{ng}$ reported by Marcussi. ${ }^{20}$

The mini-exon gene is of great value to molecular biology techniques applied to studies of leishmaniasis; in addition to the large number of copies in the genome, it contains conserved and variable regions that differ among the Leishmania complexes..$^{23}$ Derived from this gene, the LU5A-LB3C pair of primers has the ability to amplify fragments of DNA from various species of Leishmania of the L. braziliensis complex, including L. (V.) braziliensis, L. (V.) guyanensis, $L$. (V.) panamensis, and $L(V$.$) peruviana. { }^{21}$ For this pair of primers, the present study showed low sensitivities (256 fg) compared to previous studies carried out by Harris, ${ }^{19}$ studying samples from lesion scrapings from patients in South and Central America, and Gomes, ${ }^{24}$ in dogs in Brazil, with a detection level above $1 \mathrm{fg}$ of DNA.

The higher sensitivity obtained with the MP3H-MP1L primers can be attributed in part to the smaller size of the amplicon, which is amplified more efficiently than larger fragments. ${ }^{19}$ Interestingly, the B1-B2 primers showed the same sensitivity ( $4 \mathrm{fg}$ ) as the MP3H-MP1L primers, despite the size of the amplicon (750 bp), which is 10-fold larger. It is not surprising that LU5A-LB3C primers were less sensitive compared to the primers for $\mathrm{kDNA}$, because there are 50 times fewer copies of the SL RNA gene than of the kDNA minicircle, ${ }^{19}$ which explains the 100 -fold lower sensitivity. The differences in sensitivity observed among the several reports that have used the same pair of primers, can be explained by different DNA extraction methods that affect the quality of DNA. ${ }^{25}$

The conclusive laboratory diagnosis of ACL is made by demonstrating amastigote forms of the parasite in material from scrapings or biopsies from lesions, and samples of bone marrow. ${ }^{5}$ PCR has shown several advantages in the diagnosis, clinical characterization, and epidemiology of leishmaniases. Several studies of ACL caused by parasites of the L. braziliensis complex in Central and South America have compared diagnoses by PCR with the conventional technique. Except in a few cases, the tests using the PCR technique were significantly more sensitive than those using parasitological diagnostic methods. ${ }^{13,26}$ However, there is great variation in the sensitivity of PCR, especially in relation to the method of DNA extraction, the choice of the oligonucleotide primers, ${ }^{25,27,28}$ the clinical samples used, and the length of infection. ${ }^{16}$

In the present study, 26 samples from dogs (lesion scrapings, biopsy, and blood) and 47 samples from humans (lesion scrapings), from an endemic area of ACL caused by L. (V.) braziliensis, were tested by PCR using these five pairs of primers. PCR using the MP3H-MP1L primers, which amplify a fragment of the kDNA minicircle region of the subgenus Leishmania (Viannia), showed high positivity in human and canine lesions, detecting all samples that had positive parasite search. Demonstration of amastigote forms of the parasite in material from ACL lesions shows low sensitivity. Silveira ${ }^{6}$ demonstrated that only $59.4 \%$ of the patients with positive laboratorial diagnostic for ACL showed positive direct parasite search in lesions. In this way, PCR was significantly more efficient than the PD, detecting DNA in 12/20 (60.0\%) human lesion samples with negative DP. Although the B1-B2 primers detected higher number of infected samples from human than PD, its performance in canine samples was not good. On the other hand, PCR carried out with the LU5A-LB3C, in spite of a good performance in samples from human lesions with positive DP, detected only $25.0 \%$ of dog samples with positive DP and none from human samples with negative DP. It is important to emphasize that all canine and human samples analyzed had DNA quantities higher than the sensitivity limits to these primers. The presence of sufficient quantities of DNA in samples only shows that it was adequate to carry out the assay and the dilution of Leishmania DNA template by the host DNA is a fact, but it is impossible to be controlled. PCR inhibitors are a setback in clini- 
cal samples from different sources, but as all samples from DP positive lesions could be detected by MP3H-MP1L, it is supposed there were no PCR inhibitors in these samples.

LBF1-LBR1 and 13A-13B primers were less effective than DP to detect Leishmania DNA in human lesion scrapings probably due the small DNA quantities in these samples. It shows the importance of the choice of the primers pairs mainly to analyze samples that, by the characteristics from the samples collection, presents small quantities of DNA like lesion scrapings. All lesion samples detected by PCR using the less-sensitive primers were also detected by PCR using the more-sensitive primers.

Detection of DNA from Leishmania spp. in the blood samples of dogs from an endemic area has been reported by several investigators. ${ }^{15,25,29,30}$ In the present study, all PCR primers were capable of detecting Leishmania spp. DNA, with different positivity rates, in blood samples from dogs with suspected ACL lesions, whereas the DP technique produced negative results. All the canine blood samples detected by PCR using the less-sensitive primers were also detected by PCR using the more-sensitive primers, with the exception of one, which was not detected by the LBF1-LBR1 primers but was detected by the $13 \mathrm{~A}-13 \mathrm{~B}$ primers.

The diagnostic positivity rate obtained with PCR primers was corroborated by the analytical sensitivity. The MP3H-MP1L and B1-B2 primers, both targeting the kDNA minicircle, detected smaller quantities of $L$. (V.) braziliensis DNA and they showed higher positivity in the diagnosis. The MP3H-MP1L amplify a conserved sequence $^{17}$ and the B1-B2 amplify the entire kDNA minicircles of $L$. (V.) braziliensis, ${ }^{18}$ showing that the size of the amplicon did not influence the PCR. The LU5A-LB3C also showed good positivity, but only in lesion scrapings from humans. The other two pairs of primers targeting the k-DNA minicircle, 13A-13B for the genus Leishmania and LBF1-LBR1 for the species L. (V.) braziliensis, may be directed to an unconserved region in the genus and species, respectively. More studies are necessary with a larger number of Leishmania isolates, to establish the real amplitude of DNA detection for the latter pairs of primers.

\section{CONCLUSION}

In light of these results, it can be concluded that the PCR primers used in the diagnosis and epidemiology of cutaneous leishmaniasis showed a wide variation in sensitivity. Of the pairs of primers analyzed, MP3H-MP1L and B1-B2, targeting the kDNA minicircles, performed best. Compared to the direct parasite search, however, they performed significantly better, emphasizing the importance of standardizing the PCR technique, analyzing sensitivity, and choosing appropriate oligonucleotide primers.

\section{ACKNOWLEDGEMENTS}

The authors thank the Fundação Araucária and the Conselho Nacional de Desenvolvimento Científico e Tecnológico (CNPq) for financial support to carry out this study (Process No. 410550/2006-0).

\section{REFERENCES}

1. Grimaldi Jr G, Tesh RB. Leishmaniasis of the New World: current concepts and implications for future research. Clin Microbiol Rev 1993; 6:230-50.

2. Lainson R, Shaw JJ. New World Leishmaniasis. The neotropical Leishmania species. Collier L, Balows A, Sussman M, eds. Topley \& Wilson's Microbiology and Microbial Infectious Diseases. Ninth edition. Arnold, London, 1998.

3. Murray HW, Berman JD, Davies CR, Saravia NG. Advances in Leishmaniasis. Lancet 2005; 366:1561-77.

4. World Health Organization - WHO. Available at: http://www. who.int/Leishmaniasis/en/ (Accessed in 15/01/2009).

5. Gontijo B, Carvalho MLR. Leishmaniose Tegumentar Americana. Rev Soc Bras Med Trop 2003; 36(Suppl.1):71-80.

6. Silveira TGV, Arraes SMAA, Bertolini DA et al. Observações sobre o diagnóstico laboratorial e a epidemiologia da leishmaniose tegumentar no Estado do Paraná, sul do Brasil. Rev Bras Med Trop 1999; 32:413-23.

7. Armijos RX, Chico ME, Cruz ME et al. Human cutaneous Leishmaniasis in Ecuador: identification of parasites by enzyme electrophoresis. Am J Trop Med Hyg 1990; 42:424-8.

8. Camargo ME, Rebonato C. Cross-reactivity in immunofluorescence test for Trypanosoma and Leishmania antibodies. A simple inhibition procedure to ensure specific results. Am J Trop Med Hyg 1969; 18:500-5.

9. Badaro R, Reed SG, Barral A, Orge G, Jones TC. Evaluation of the micro enzyme-linked immunosorbent assay (ELISA) for antibodies in American visceral Leishmaniasis: antigen selection for detection of infection-specific responses. Am J Trop Med Hyg 1986; 35:72-8.

10. White T, Madej R, Persing D. The polymerase chain reaction: clinical applications. Adv Clin Chem 1992; 29:161-96.

11. Harris E, Lopez M, Arevalo J et al. Short courses on DNA detection and amplification in Central and South America: the democratization of molecular biology. Biochem Educ 1993; 21:16-22.

12. Harris E, Belli A, Agabian N. Appropriate transfer of molecular technology to Latin America for public health and biomedical sciences. Biochem Educ 1996; 24:3-12.

13. Medeiros ACR, Rodrigues SS, Roselino AMF. Comparison of the specificity of PCR and the histopathological detection of Leishmania for the diagnosis of American cutaneous leishmaniasis. Braz J Med Biol Res 2002; 35:421-4.

14. Garcia FCB, Santos SSR, Chociay MF, Medeiros ACR, Roselino AMF. Métodos subsidiários para o diagnóstico da leishmaniose tegumentar americana (LTA): comparação dos resultados do seqüenciamento de DNA e da PCR-RFLP para determinação da espécie de Leishmania em amostras cutâneo-mucosas. An Bras Dermatol 2005; 80(Suppl.3):340-5.

15. Velasquez LG, Membrive N, Membrive H et al. PCR in the investigation of canine American tegumentary leishmaniasis in Northwestern Paraná State, Brazil. Cad Saúde Pública 2006; 22:571-8. 
16. Venazzi EA, Roberto AC, Barbosa-Tessmann IP, Zanzarini PD, Lonardoni MV, Silveira TG. Polymerase chain reaction with lesion scrapping for the diagnosis of human American tegumentary leishmaniasis. Mem Inst Oswaldo Cruz 2006; 101:427-30.

17. Lopez $\mathrm{M}$, Ingá $\mathrm{R}$, Cangalaya $\mathrm{M}$ et al. Diagnosis of Leishmania using the polymerase chain reaction: a simplified procedure for field work. Am J Trop Med Hyg 1993; 49:348-56.

18. De Bruijn MHL, Barker DC. Diagnosis of new world Leishmaniasis: specific detection of species of the Leishmania braziliensis complex by amplification of kinetoplast DNA. Acta Trop 1992; 52:45-58.

19. Harris E, Kropp G, Belli A, Rodriguez B, Agabian N. Singlestep multiplex PCR assay for characterization of New World Leishmania complexes. J Clin Microbiol 1998; 36:1989-95.

20. Marcussi VM, Marcussi LM, Barbosa-Tessmann IP, Lonardoni MV, Silveira TG. Leishmania (Viannia) braziliensis: New primers for identification using polymerase chain reaction. Exp Parasitol 2008; 120:300-5.

21. Rodgers MR, Popper SJ, Wirth DF. Amplification of kinetoplast DNA as a tool in the detection and diagnosis of Leishmania. Exp Parasitol 1990; 71:267-75.

22. Manna L, Vitale F, Reale $S$ et al. Comparison of different sampling for PCR-based diagnosis and follow-up of canine visceral leishmaniosis. Vet Parasitol 2004; 125:251-62.

23. Fernandes O, Bozza M, Pascale JM, de Miranda AB, Lopes UG, Degrave WM. An oligonucleotide probe derived from kDNA minirepeats is specific for Leishmania (Viannia). Mem Inst Oswaldo Cruz 1996; 91:279-84.
24. Gomes AH, Ferreira IM, Lima ML et al. PCR identification of Leishmania in diagnosis and control of canine Leishmaniasis. Vet Parasitol 2007; 144:234-41.

25. Reithinger R, Lambson BE, Barker DC, Davies CR. Use of PCR to detect Leishmania (Viannia) sp. in dog blood and bone marrow. J Clin Microbiol 2000; 38:748-51.

26. Rodriguez N, Guzman B, Rodas A, Takiff H, Bloom BR, Convit J. Diagnosis of cutaneous Leishmaniasis and species discrimination of parasites by PCR and hybridization. J Clin Microbiol 1994; 32:2246-52.

27. Ikonomopoulos J, Kokotas S, Gazouli M, Zavras A, Stoitsiou M, Gorgoulis VG. Molecular diagnosis of Leishmaniasis in dogs: comparative application of traditional diagnostic methods and the proposed assay on clinical samples. Vet Parasitol 2003; 113:99-113.

28. Bensoussan E, Nasereddin A, Jonas F, Schnur LF, Jaffe CL. Comparison of PCR assays for diagnosis of cutaneous Leishmaniasis. J Clin Microbiol 2006; 44:1435-9.

29. Llanos-Cuentas EA, Roncal N, Villaseca P et al. Natural infections of Leishmania peruviana in animals in the Peruvian Andes. Trans R Soc Trop Med Hyg 1999; 93:15-20.

30. Reithinger R, Espinoza JC, Coutenay O, Davies CR. Evaluation of PCR as diagnostic mass-screening tool to detect Leishmania (Viannia) spp. in domestic dogs (Canis familiaris). J Clin Microbiol 2003; 41:1486-93. 